\title{
The Effects of Law Through Actions of Inspections ${ }^{1}$
}

\author{
Mirko Pečarič \\ University of Ljubljana, Faculty of Administration, Slovenia \\ mirko.pecaric@fu.uni-lj.si
}

\section{ABSTRACT}

Regulated phenomena in changing environments are difficult to manage. Their complexity is many times higher that can usually be embraced in the conventional ways public administrations prepare draft statutes, adjudicate and control other people. The same or even more stands for inspections as public bodies that directly see "regulations in action", how asymmetries between regulation and implementation arise. Inspection is in the context of executive tasks despite its age a relatively new and poorly understood element of regulatory policies. This paper claims that regulation and enforcement are two sides of the same coin: only "regulation-enforcement" (feed-in) and "enforcement-regulation" (feedback) are the "eyes and ears" of effective regulation. Without the latter, when rules are realistic and adequate for a given context, no amount of enforcement will make unrealistic rules work. At the same time, without the properly administrated enforcement steps, focused on the risk-analysis, risk-management (risk-based strategic planning), monitoring and sufficient resources, no amount of otherwise good regulation will provide expected results.

Key words: control, public administration, inspections, implementation, regulation.

$J E L: K 42$

Les lois inutiles affaiblissent les lois nécessaires.

- Montesquieu ${ }^{2}$

\section{Introduction}

At a time when public confidence in the functioning of public administration institutions becomes more and more fragile, when public confidence in the work of state institutions is very low (electoral participation included), each institution must rethink/contemplate its concept of action. This is all the

1 This article is a revised version of the paper entitled 'The Importance of Inspection for Achieving Public Goals', presented at the EGPA Conference, Milano, 30 August-1 September, 2017, co-authored with Polonca Kovač. The EGPA contributions are not publicly available.

2 The whole Montesquieu's sentence is: '[a]s useless laws debilitate such as are necessary, so those that may be easily eluded, weaken the legislation. Every law ought to have its effect, and no one should be suffered to deviate from it by a particular exception' (1989, p. 598) 
truer for the supervisory, repressive institutions of the state among which are also inspection services. Inspection is in the context of executive tasks despite its age ${ }^{3}$ a relatively new and poorly understood element of regulatory policies; this can be inferred from the lack of literature and analysis on this topic (on the subject of inspections there is surprisingly little literature on their home field, i.e. administrative law, while e.g. also on Amazon.com or Google Books cannot be found not even one systematic work on this subject), although there are some, rare exceptions (Blanc, 2012; Jacobs \& Cordova, 2005; Monk, 2012; OECD, 2013, 2014; Palast, Oppenheim, \& MacGregor, 2003). Inspections are one of the basic administrative functions that control compliance with general rules. Qualitative, analytical, development-oriented and proactive inspection in the sense of understanding the authority, that is the highest when it is not even used (Arendt, 1972; Luhmann, 2013), it also has a wider task and objective; it must strive for preventive, advisory work, it must search for ways to connect performance with less burden on taxpayers. Among future challenges for countries will be the development and application of enforcement tools for the best possible outcomes with the highest compliance levels and minimum costs and burdens. Regulations as the formal tools of public power have been the subject of numerous debates (who can enact or change them, in what way, how, where and why, in what way they can be "good, better, smart, [really] responsive" etc.), but very seldom how they are de facto implemented, what enforcement tools are available, i.e. how information exchange takes place. ${ }^{4}$ This paper based on the latter sentence tries to point on circumstances which regulation should not disregard, and presents the inspection as an enforcement action in its wider context, because only a better understanding of the concepts of control (horizontal, between equal partners) and supervision (vertical, between unequal, vertically superior and/or subordinated members) can lead us to a better understanding of inspection's work. In two parts there are four combinations, and the same could stand for regulation and implementation. A research question of this paper therefore is:

3 The growth and rapid industrialization led to political demands for the increased regulation and control of the urgent capitalist order also in antebellum America, where inspections i.e. the Steamboat Inspection Act of 1837 worked before the first regulatory agency (the Interstate Commerce Commission) was established in 1887 (Schiller, 2016).

4 One effective example of information exchange presents the UK's Regulatory Delivery as the part of Department for Business, Energy \& Industrial Strategy, that 'brings together policy expertise and practical experience to ensure that regulation is effectively delivered in ways that reduce burdens on business, save public money and properly protect citizens and communities'. (Regulatory Delivery, 2017) Among the interesting coordinate enforcement action tools is the regulators' development needs analysis (RDNA) as a self-assessment tool with technical knowledge sections specific to areas of regulation, and Primary Authority that enables businesses to obtain from authorities consistent advice on compliance with regulation, in a tailored and cost effective manner. Primary Authority advice is assured - the primary authority may direct against enforcement action if it is deemed to be inconsistent with the advice given - and this gives businesses the confidence to invest and grow. PA represents a new way of regulating, in which regulators work closely with businesses to ensure compliance while encouraging growth. Since PA began in 2009, the scheme has been extended to include more areas of regulation and to enable more businesses to participate. Businesses which are regulated by multiple local authorities are able to partner directly with a primary authority or are able to access the scheme via a coordinator such as a trade association (Department for Business, Energy \& Industrial Strategy, 2017, p. 5). 
Can regulation and implementation as two faces of Janus's coin be understood separately, or be regulated and implemented separately?

An answer will be given with the help of literature review, the OECD and EU practice, the basic notions of regulatory cycle and systems management; the first will be presented also in picturesque mode because we a la Aristotle (2016) believe the soul never thinks without an image. Results could be helpful for regulators and inspections to work more separately or more closely. As an answer is almost intuitively given to a reader a problem is obviously somewhere else. It definitely has something to do with implementation, which is also the focus point of this paper.

\section{Circumstances which Regulation Should not Disregard}

One of the most quoted propositions in Spinoza's Ethics is 'the order and connection of ideas is the same as the order and connection of things and vice versa' (Descartes, Spinoza, \& Leibniz, 1974, p. 382). Thoughts and facts are indeed tightly connected; one without other can only be idealism or materialism. But how come this intuitive thought is so hard to apply in real occasions, in regulation? Countries e.g. many times enact, change or amend regulations a la Alice in Wonderland, who just wanted to go from one place "so long as I get somewhere". This behaviour is spotted when regulators do not connect ideas with facts and vice versa, when they are always on the move and always regulate something, but they basically do not know what they (will) cause, despite of the even knowable, legally determined goals. The basic frame in which goals are achieved in democratic countries is the division of power between the legislative and executive branch; this (common-sense) division also divides proclaimed goals and their factual achievement. Already for Goodnow administration was the function of executing the will of the state or the expression of the political will (Goodnow, 1900, 1905), formally in general rules determined in the notion of public interest. Although he made the difference between the expression (politics) and execution (administration) of the state will, he also knew 'the administrative system may, however, be so arranged as to make the actual practice quite contrary to the theory' (1900, p. 29). Duguit as one of the most vivid promoters of the country as public service, claimed 'a legal system is real only in the degree in which it creates rules satisfying the needs of men in a given society at a definite moment of time' (1921, p. 25). Despite this intuitive and rational division between the interests and the objective possibilities of their achievement (between theory and practice), and despite intuitive knowledge that goals can be effectively achieved only through the good implementation of (regulatory) goals, only regulation - as only one of the country's ius imperii instruments - has been mostly emphasised on the expense of rules' implementation.

Sometimes new terms/institutions are developed solely to embrace the non-effective practices (this can be confirmed from their names, e.g. good 
administration, good governance, responsive, better, smart regulation), although the basic ideas stay the same: "if you want to accomplish your goals, you must have appropriate tools to do so", and "if you want to determine your goals, you must have appropriate facts established with proper tools". This obviously right and intuitive idea could be wrong, because it fits into Newton's second law of motion, ${ }^{5}$ as a classic example of a one-way causeeffect thinking. It disregards the mental, internal processes of living organisms, which are able to control aspects of their external environments. Cziko describes this as circular causality in which causes are also effects and the latter are also causes: 'perceptions do not control behaviour. Rather, individuals vary their behaviour as necessary to control their perceptions and thereby obtain desired outcomes and avoid unwanted ones' (2000, p. 253). If one-way cause-effect relation was a long time the main prerogative, the theory of complex adaptive systems gives a fresh insight into living systems with a concept of emergence: '[a]n emergent property is a global behaviour or structure which appears through interactions of a collection of elements, with no global controller responsible for the behaviour or organization of these elements. The idea of emergence is that it is not reducible to the properties of the elements' (Feltz, Crommelinck, \& Goujon, 2006, p. 241). All is not only more than the sum of its parts, but what is or could be "all" cannot be known in advance; it emerges only through interaction. A very similar concept is the concept of synergy that means 'behaviour of whole systems unpredicted by the behaviour of their parts taken separately' (Fuller \& Applewhite, 1997, p. 59). ${ }^{6}$

Although in regulation emphasis is put on goals and tools by which the former can be achieved, their relations are mostly forgotten: not only tools are chosen to achieve goals, but also the first constantly and in a new way co-define the second during their usage. What will "(re)emerge" from some regulations therefore crucially depends on the interaction of all (legal, factual, personal, organisational, financial, etc.) parts. A further characteristic of this emergent property is its 'complex behaviour [that emerges] from simple rules. Those rules imply general regularities, but the working out of an individual case exhibits special regularities in addition' (Gell-Mann, 2002, p. 313). How this could be relevant for regulation? The "emergent idea of regulation" is that if you want goals, focus on a system in which goals are achieved, i.e. focus on processes, their interactions, build the real-time feedback loops and establish transparency for all stakeholders and citizens. Despite all efforts, final goals can be more (known today - in the absence of the mentioned emergent idea of regulation - as unintended consequences) or less (our goal) different. On a

5 The acceleration of an object as produced by a net force is directly proportional to the magnitude of the net force, in the same direction as the net force, and inversely proportional to the mass of the object (Newton, 1947).

6 Emergence and synergy could not only explain why 'rational, self-interested individuals will not act to achieve their common or group interests' (Olson, 2002, p. 2), or the fact that 'even if each individual of firm were rational, that would not ensure systemic stability' (Stiglitz, 2009, p. 17). 
general (regulatory) level a system is needed in which information asymmetries are minimised in a quick manner (this include also the moral hazard and human fallibility).

Breyer - as one of the first "ice-breakers" of the field of regulation - in 1982 claimed regulation cannot be described only in legal terms: 'to generalize usefully about regulation, one must understand the substance of the regulatory program' (S. Вreyer, 1982, p. vii). He presented in Regulation and Its Reform a system of categorising regulation. Although he suggested caseby-case approach to regulatory reform, i.e. detailed examination of individual agencies (with sunset proposals and agency-by-agency review), and devoted to that area some (only three) pages (S. Breyer, 1982, pp. 365-368) it was not enough (not even in 2006 ${ }^{7}$ ) to start the story of regulation de facto on both (determination and implementation) sides. Ex post evaluation is 'vital to the successful implementation of...legislation' (Gunningham, 2012, p. 120); there is much literature about the responsive (Аyres \& Braithwaite, 1995), smart (Gunningham, Grabosky, \& Sinclair, 1998), meta (Chiu, 2015) or risk-based regulation (Black, 2012), but there are rare works focused on the implementation level: Baldwin, Cave and Lodge propose to regulators a broad regulatory process with five core tasks (the DREAM framework): detecting, responding, enforcing, assessing and modifying (Baldwin, Cave, \& Lodge, 2013, p. 227), while for Black regulators should practice really responsive regulation, ${ }^{8}$ but a common denominator of most is the regulator, not the implementer. In documents ex post evaluation is mentioned already in the origins of regulatory impact assessment ${ }^{9}$, but it was rarely de facto executed. For almost three decades, ex ante regulatory impact assessment was the "regulatory star". The UK Better Regulation Task Force in 2003 among the five principles of good regulation included proportionality, accountability, consistency, transparency and targeting. Although only the latter (regulation should be focused on the problem, and minimise side effects) fulfils some parts of our emergent idea of regulation (enforcers should focus primarily on those whose activities give rise to the most serious risks, and regulations should be systematically reviewed to test whether they are still necessary and effective), it disregards that targeting depends crucially on data which have mostly implementers (street-level bureaucracy), not regulators. The OECD in 2006 noted 'there is, as yet, little evidence of the systematic adoption of

7 Breyer with co-authors in 2006 issued a large work on administrative law, but on the subject of regulation the typical justifications for regulation and the classic regulatory tools are very briefly mentioned (S. G. Breyer, Stewart, Sunstein, \& Vermeule, 2006, pp. 4-13).

8 To be "really responsive" regulators have to respond not merely to firms' compliance responses, but also to their behaviour, attitudinal settings, to the broader institutional setting of the regulatory regime; to the different logics of regulatory tools and strategies; to the regime's own performance; and finally, to changes in each of these elements (Baldwin \& Black, 2007, p. 17).

9 In one of the first OECD's documents on the subject of regulation, the OECD Report on Regulatory Reform (1997) ex post evaluation (review regulations systematically to ensure that they continue to meet their intended objectives efficiently and effectively and ensure that regulations and regulatory processes are transparent, non-discriminatory and efficiently applied), was also mentioned, but on the national levels this was not enough for its serious application. 
ex post assessments of the ex ante predictions about probable regulatory impacts made in RIA documents - that is, of "outcome testing"' (OECD, 2006, p. 33), but in 2009 it already found a number of authorities using RIA methods to strengthen their evidence-based policy making in the area of corporate governance. It suggested that also in areas where 'a need to act quickly [exists]...best practice indicates that there should at least be an ex post analysis to determine whether the emergency or hastily introduced measures were indeed effective and efficient' (OECD, 2009, pp. 178-179). ${ }^{10}$ Despite efforts, 'the processes of how regulations are designed and developed, how to improve them and make them "smarter", have been given considerably more study than the regulatory delivery mechanisms of inspections and other enforcement tools' (OECD, 2013, p. 4). Improving the design of regulation through regulatory impact analysis, stakeholder engagement and the removal of unnecessary burdens has prevailed 'over regulatory enforcement in most OECD countries so far. Scarce attention has been paid to examining possibilities for improving the way regulations are implemented and enforced' (OECD, 2014, p. 3). ${ }^{11}$ Although countries gave in recent year a large attention to administrative burden reduction, the latter unfortunately does not (also due to data incompatibility) incorporate data which inspections has:

Though in theory it should be possible to use data from inspectorates themselves to estimate the burden [reduction] and its evolution, in practical terms this is usually impossible. Inspectorates tend to be reluctant to share this data but, even when they do, its structure is often inadequate to this purpose (difficult in most countries to calculate really how many different businesses were inspected, as distinct from how many visits took place), and its contents not detailed enough (e.g. On duration of visits) (Blanc, 2012, p. 49).

The OECD's international standard cost model (SCM) that is also used in the EU and its member states does not include enforcement or inspection costs (European Commission, 2007; SCM network, 2016). ${ }^{12}$ In December 2012, the European Commission upgraded its efforts in the field of Smart Regulation by launching the Regulatory Fitness and Performance Programme (European Commission, 2014), aimed at eliminating unnecessary regulatory burdens and ensuring that the body of EU legislation remains fit for purpose.

10 A connection between efficiency and effectiveness can be vividly expressed in Ackoff's (1978) relation between doing the "right thing wrong" (effective inefficiency) or the "wrong thing right" (ineffective efficiency). The more efficient people/administrators are at the doing the wrong (ineffective) thing, the wronger they become.

11 Based on this observation the OECD (2014) developed the eleven principles addressing the design of the policies, institutions and tools for promoting effective compliance and the process of reforming inspection services to achieve results. The way inspections are planned, their better targeting, communication with regulated subjects, preventing corruption and ethical behaviour could be based on '1. Evidence-based enforcement; 2. Selectivity; 3. Risk focus and proportionality; 4. Responsive regulation; 5. Long-term vision; 6. Co-ordination and consolidation; 7. Transparent governance; 8. Information integration; 9. Clear and fair process; 10 . Compliance promotion; and 11. Professionalism.

12 The SCM uses a formula to measure the administrative burdens (Cost per administrative activity [or per data requirement] = Price $\mathrm{x}$ Time $\mathrm{x}$ Quantity [population $\mathrm{x}$ frequency]). Administrative costs as defined by the SCM are only incurred where the inspection relates entirely to an information obligation. Inspections with a broader focus are not included (SCM network, 2016, p. 41). 
Among horizontal actions the Commission enumerated beside the impact assessment, stakeholder consultation, measurement of regulatory costs and benefits and reporting requirements, also ex-post evaluation (as a clear sign that ex post evaluation is usually not taken into account in impact assessment) that verifies whether the expected results and impacts of EU regulation have been achieved (inspections are not mentioned). The High Level Group on Administrative Burdens (HLG) that was set up in 2007 to advise the Commission on the implementation of the Action Programme for Reducing Administrative Burdens in the European Union among five recommendations recommends 'that the Commission develops a common EU methodology to measure regulatory costs and benefits, makes the evaluation of all EU legislation compulsory on the basis of this common methodology to measure actual outcomes against original objectives before any proposal for revision or new legislation is made' (The High Level Group on Administrative Burdens, 2014, p. 53).

On the EU level, a serious step towards ex post evaluation was made with the Regulatory Scrutiny Board (RSB) that replaced in 2015 the Impact Assessment Board (IAB) of 2006. ${ }^{13}$ The IAB enforced quality standards for the impact assessments for Commission proposals, but the Juncker Commission ${ }^{14}$ wanted to achieve more in better regulation. It established the RSB in 2015 with reinforced independence and enhanced responsibilities to cover "fitness checks" and significant ex post evaluations of existing policies. The goal is to ensure that evaluations supporting Commission policy-making are of high quality. This helps make operational what is commonly referred to as the "evaluate first" principle. The RSB explained how the "evaluation first" principle works in practice:

The RSB looks only at fitness checks and the most important evaluations; the selection of the planned evaluations is based on the Commission's multi-annual evaluation planning. Evaluated services are obliged to write a Staff Working Document (SWD) that summarises the evaluation and its conclusions. The Board's opinion on evaluations focuses on the quality of the SWD. The few (seven) SWDs that the Board reviewed over the past year had limited critical analysis of such issues as coherence, relevance and EU value added. They also did not systematically draw clear conclusions for follow-up action and did not always exploit all the information that external evaluators had collected. By contrast, the analysis of efficiency and effectiveness was more complete. All evaluations should constitute an essential input to the corresponding impact assessment. The RSB sees evaluations together with the impact assessment and can include its assessment of their quality in the opinion it provides on the impact assessment. In the course of 2016, has seen and reviewed another

13 The European Commission already in 2010 stated that 'the Commission will target the whole policy cycle by attaching more importance to the evaluation of existing legislation and policies. The resulting evidence will be put at the heart of the design of new or revised regulation, alongside with impact assessments'. IP/10/1296, 8 October 2010. http://europa.eu/rapid/ press-release_IP-10-1296_en.htm?locale=en

14 Decision of the President of the European Commission on the Establishment of an Independent Regulatory Scrutiny Board, Strasbourg, 19.5.2015 C(2015) 3263 final. 
15 evaluations in this way. Overall, it appears that at least half of the impact assessments applied the "evaluation first" principle in 2016. The "evaluation first" principle increases transparency. Board review of the SWDs also provides an institutional safeguard against "cherry-picking", i.e. selectively reporting evidence that supports a particular approach. The presence of such a safeguard serves to increase the credibility of evaluation practices (Regulatory Scrutiny Board, 2016, p. 17).

The RSB's focus on evaluations done by services which implement regulations is very relevant (implementers have the largest amount of information that emerges at the very time of rule implementation), but on a long run, the "evaluation first" principle should become a part of the regulatory culture of each institution per se.

\section{An Inspection as an Enforcement Action}

Regulation and enforcement are two sides of the same coin; as for every two parts, also here we have four combinations: "regulation-regulation" is blind and ineffective, "enforcement-enforcement" (without rules) is deaf and illegal, while "regulation-enforcement" (feed-in) and "enforcementregulation" (feedback) are the "eyes and ears" of effective regulation. Without effective regulation, when rules are realistic and adequate for a given context, no amount of enforcement will make unrealistic rules work. At the same time, without the properly administrated enforcement steps, focused on the risk-analysis, risk-management (risk-based strategic planning), monitoring and sufficient resources, no amount of otherwise good regulation will provide expected results. The effective and efficient regulation is constantly in regulators' focuses, but both terms are also tightly connected with enforcement. ${ }^{15}$ In recent years grows a recognition that also ensuring effective compliance with rules and regulations is the important factor in creating a well-functioning society and trust in government (OECD, 2013, 2014). Enforcement represents the classic types of rules' implementation (advice, warning, sanction) conducted by regulatory agencies and lawenforcement bodies (penalty, prosecution), as well as the other legal or even potential actions of agencies (proposals for legal changes, public notices, naming and shaming), of third parties (actio popularis, qui tam) or even of undefined populations (loss of confidence, demonstrations, media). Among enforcement tools that stand up front by the number of legal procedures, employees, competencies for a forced execution or repression with grave consequences for persons subjected to legal obligations, are inspections as 'any type of visit or check conducted by authorised officials on products or business premises, activities, documents etc.' (OECD, 2013, p. 3).

15 Due to the mentioned notions of emergence and synergy, enforcement could be even more important than regulation, because new emergent properties can be spotted only in this stage of regulatory cycle. 
The operation of inspections is provided by public funds, so the public rightly expects funds are used in the rational and efficient manner. All this is true, but it is already a result which is determined by their approach. An activity of public institutions should be transparent, efficient and responsive to the public needs. This is even more true for the controlling and/or repressive institutions of the country. Despite the increasing focus or even quite continuous efforts to eliminate administrative burdens, the field of inspections continues to be the field with low-interest for it. There are numerous talks about the better transparency, efficiency, responsiveness and other unspecified concepts, but very seldom what they mean in practice and/or how they are put into practice. In connection with the achievement of public objectives, the public attention has been so far largely devoted to the "art of regulation", while techniques, i.e. the enforcement tools of the very same regulation, has remained somehow by the side. There is ample evidence that inspections are crucial for the determination how regulations are viewed from businesses and the economy. Based on the analysis of 25 respondent states about inspections Monk concludes that despite 'much good practice taking place there is still a high level of complexity, considerable inconsistency and a general gap in the way inspection authorities are governed and their performance of inspections implemented and assessed' (Monk, 2012, p. 4).To Blanc

inspections and enforcement actions are generally the primary way through which businesses, "experience" regulations, and regulators; inadequate approaches in enforcement and inspections can mean that changes in regulations fail to deliver their full benefits, evolutions in inspections and regulatory delivery to make them more compliance-focused, more supportive and risk-based can all lead to real and significant improvements for economic actors, enforcement and inspections are as much about methods and culture as institutions, and as much about organizational mechanisms as legislation (Blanc, 2012, p. 7).

Each inspection should conduct its work by checking not only the compliance of operations with regulations but also the public opinion (also through application forms, anonymous tips, affairs) vis-à-vis individual activities (how they are performed, what kind of relationship is to and between the parties, etc.), what kind of attitude of a subject inspected has towards inspections and thereby (as well as by asking questions) analyse - based on the data and views of all participants - a situation of individual activities, present proposals for legislative changes and the like. Control through inspections should not be implemented just as simply control about an implementation of laws (which leads to technicism and bureaucratisation of those services), but it should monitor the application of the law particularly to protect the public interest in connection with the rights of individuals. The principles of proportionality, independence, and professionalism of the inspection should occur therefore at the very beginning, in the forefront of their work. Inspections are used on areas where a penalty for infringement is not fully automatic (where it can be determined directly from records, reports, etc.), and/or where a specific knowledge to detect violations is needed. Thus, in addition to the classic 
legal bases understanding is needed about ways of practical implementation of regulation, how the interaction between the inspection and taxpayers is developed, how practices can be harmonised, and results measured and finally how a relevant field can be directed towards the desired goal. Notwithstanding that a system of external control must be present, there should be also established an internal system of control that not only monitors but also manages. This duality can be sometimes or somewhat overlooked, but it was always known; French know it in the adage: juger l'administration, c'est encore une fois administer. As soon as a certain activity is regulated under the law, its implementation must be such that rules are not violated. A guarantee for this is primarily a public body/person that/who implements activities, and not a higher supervisory authority - even if the latter has a controlling function determined as one of its main tasks (inspection, a court of audit). A duty to control is never solely a function of control, but through it, an appropriate dose of control activities is also administrated.

Control processes are the generator of the executive, repressive apparatus; it is essential the methods, scope and resources are in the work of scheduled inspections, coordinated and controlled, and especially in a constant contact with the area where they are implemented. In the time of growing intertwining of fields, the complexity of the work, development of technologies etc., it is important the tactic of inspection is not just a matter of an individual inspection or even multiple inspections, but of all stakeholders, which may be affected by the work of the first. The inspection is only one element of control; the original inspection should be carried out already within a scope of individual activities. In addition to the repressive, the inspections can - by itself or in combination with repressive measures - also use educational approaches to provide a voluntary operation, which should be in accordance with regulations, i.e. when inspector "speaks softly, but with a long stick in his hand". The inspector is not only an officer, a scientist, and an artist but the combination of everything. We can get to the very core of inspections, not through a study of individual laws, but we need to know their practices. The mentioned arguments about the wider significance of (systematic) management can be carried out also by inspections along with their traditional repressive powers. This lead us towards a clear understanding of regulatory circle and the extraction of management criteria in the field of inspection. As regulation and enforcement are two sides of the same coin, their basic elements are a mirrored picture of both sides. Both sides are established and implemented in a given country's context, i.e. in its world-view (ger. weltanschauung) and different interest from its environment that affect their content: 
Figure 1. Regulation and Enforcement Cycle (own construction)

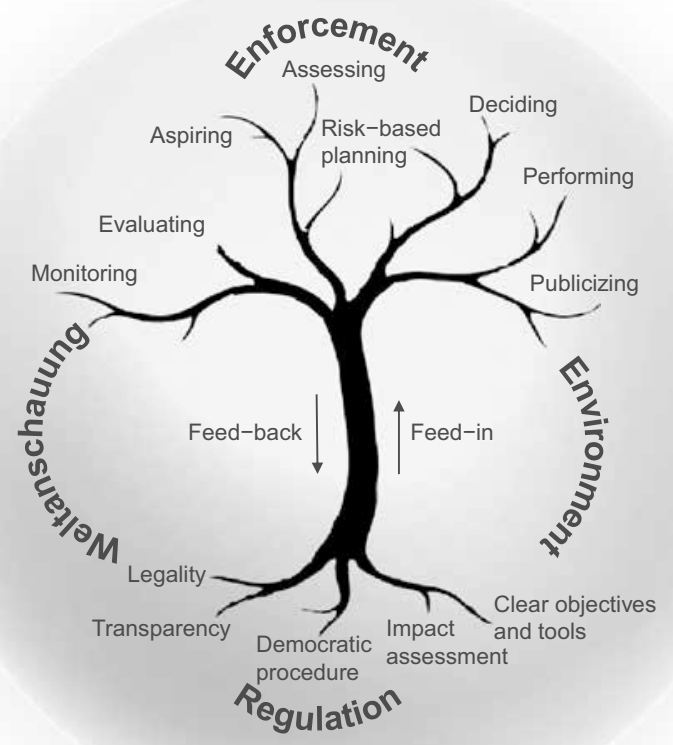

The implementation of control depends on the types of implementation, while the latter are not only associated with the problem of the recruitment of suitable staff but also how public employees understand the environment in which they work, their personal characters or world views. A system of control also depends on the education, training and competence of supervisors, but before all these and other possible fields should be considered, there must be consideration of the ways of control, their types and methods, as these have a significant impact on final results. The research question from the introduction of this paper is answered negatively: regulation and implementation cannot be understood separately, nor cannot be regulated and implemented separately. Regulators and inspections should therefore work closer, but the problem is not a system per se, but people (officials, politicians) who do not (want to) understand that complex adaptive systems always develop in their own ways (they find their own equilibrium, they are self-adaptive) if not administrated by the people.

\section{Conclusion}

Because of the ex ante impossibility of knowable (emergent) effects, it is of crucial importance that all elements are detected as soon as possible. Only through the non-stop feedbacks, (ге)organisations and (ге)arrangements of elements, control can be constantly (re)acquired over new situations 
that emerge during a change of different conditions or appear during an implementation of rules. The biggest challenge for countries is the formulation and application of strategies for the implementation of legal rules to ensure the best results with the highest possible level of compliance. The formulation-application-implementation trinity should be done while keeping regulatory costs and administrative burdens as low as possible. The activities of public institutions should be transparent, efficient and responsive to the needs in their areas. All this may be true, but it already represents a result that is conditioned by an appropriate way of getting things done. Each institution should conduct its work not only in compliance with the rules; activities should be done parallel with public opinion that the public has vis-avis various activities, including with the public body's self-evaluation.

Control should not be carried out as a mere control of the application of the law, but for the protection of the public interest and public gains concerning the rights of individuals. Only a detailed understanding of the concepts of control, supervision, and inspection can lead us to a better understanding of inspection's work, which should not be based solely on the repressive "command and control" (where power flows only one way in the form of instructions and commands,) but also on routing-benefits of adaptation, provided by a two-way communication. Information is acquired also by persons outside inspections, by the taxpayers, competitors, consumers and citizens; it can be obtained through implementing powers in the field (ex post after the occurrence of an accident, by corrective measures or ex ante in relation to the complaints, anonymous tips, from other national authorities and planned inspections), with a request to present documents from persons liable to act according with rules, or through a commitment to have records about an inspected activity. A function of control so therefore never only the function of control, but through it (with the "appropriate dose of control") also a relevant field is managed. Future research on this field could focus in systemic preparation of inspections' reports with the separate fields for communication with stakeholders and the public, for the control, preventive and repressive actions, risk assessment/management, and the last, but not least, for citizen participation and other democratic elements. We should not forget the best repressive institution is the one that never/very rarely uses its legal power to coerce its fellow-citizens. In Slovenia, e.g. decisionmakers could begin with a new version of Inspection Council's draft report for future reports; it could be more valuable than to amend Inspection Act...

Mirko Pečarič, PhD, works as an associate professor at the University of Ljubljana, Faculty of Administration where he supplements pedagogical activities with research. So far, he taught the courses of Administrative Law, Public services, Introduction to Law and the Theory of public administration. He wrote a series of legal opinions, requirements to assess a constitutionality of laws; he is the author of three monographs and numerous scientific articles. 


\section{References:}

Ackoff, R. L. (1978). The Art of Problem Solving: Accompanied by Ackoff's Fables. New York: John Wiley \& Sons.

Arendt, H. (1972). Crises of the Republic: Lying in Politics, Civil Disobedience on Violence, Thoughts on Politics, and Revolution. Harcourt Brace Jovanovich.

Aristotle. (2016). On the Soul. CreateSpace Independent Publishing Platform.

Ayres, I., \& Braithwaite, J. (1995). Responsive Regulation: Transcending the Deregulation Debate. New York; Oxford: Oxford University Press.

Baldwin, R., \& Black, J. (2007). Really Responsive Regulation. Modern Law Review, (71), 59-94.

Baldwin, R., Cave, M., \& Lodge, M. (2013). Understanding Regulation: Theory, Strategy, and Practice (2 ${ }^{\text {nd }}$ edition). New York: Oxford University Press.

Black, J. (2012). The Role of Risk in Regulatory Processes. In R. Baldwin, M. Cave, \& M. Lodge (Eds.), The Oxford Handbook of Regulation (Reprint edition, pp. 302-348). Oxford; New York: Oxford University Press.

Blanc, F. (2012). Inspection Reforms: Why, How, and With What Results. OECD Publishing.

Breyer, S. (1982). Regulation and Its Reform. Cambridge, Mass.: Harvard University Press.

Breyer, S. G., Stewart, R. B., Sunstein, C. R., \& Vermeule, A. (2006). Administrative Law and Regulatory Policy: Problems, Text, and Cases ( $6^{\text {th }}$ edition). New York, NY: Aspen Publishers.

Chiu, I. H.-Y. (2015). Regulating (From) the Inside: The Legal Framework for Internal Control in Banks and Financial Institutions. Oxford and Portland: Hart Publishing.

Cziko, G. (2000). The Things We Do: Using the Lessons of Bernard and Darwin to Understand the What, How, and why of Our Behavior. Cambridge: MIT Press.

Department for Business, Energy \& Industrial Strategy. (2017). Unlocking the Potential of Primary Authority. Crown copyright. Retrieved from https:// www.gov.uk/government/uploads/system/uploads/attachment data/ file/591042/pa-consultation-implementing-the-enterprise-act-2016.pdf

Descartes, R., Spinoza, B. de, \& Leibniz, G. W. V. (1974). The Rationalists: Descartes: Discourse on Method \& Meditations; Spinoza: Ethics; Leibniz: Monadology \& Discourse on Metaphysics. New York: Anchor Books.

Duguit, L. (1921). Law in the Modern State. (F. Laski \& H. Laski, Trans.). London: George Allen \& Unwin Ltd.

European Commission. (2007). Action Programme for Reducing Administrative Burdens in the European Union, COM(2007) 23 final. European Commission.

European Commission. (2014). Regulatory Fitness and Performance Programme (REFIT): State of Play and Outlook/COM/2014/0368.

Feltz, B., Crommelinck, M., \& Goujon, P. (2006). Self-organization and Emergence in Life Sciences. Springer Science \& Business Media.

Fuller, R. B., \& Applewhite, E. J. (1997). Synergetics: Explorations in the Geometry of Thinking. London; New York: MacMillan.

Gell-Mann, M. (2002). The Quark and the Jaguar (VIII edition). New York: W.H. Freeman \& Company.

Goodnow, F. J. (1900). Politics and Administration: A Study in Government. London: The MacMillan Company. 
Goodnow, F. J. (1905). The Principles of the Administrative Law of the United States. New York, London: G.P.Putnam's Sons.

Gunningham, N. (2012). Enforcement and Compliance Strategies. In R. Baldwin, M. Cave, \& M. Lodge (Eds.), The Oxford Handbook of Regulation (Reprint edition, pp. 120-145). Oxford; New York: Oxford University Press.

Gunningham, N., Grabosky, P. N., \& Sinclair, D. (1998). Smart Regulation: Designing Environmental Policy. Oxford: Oxford University Press.

Jacobs, S., \& Cordova, C. (2005). Good Practices for Regulatory Inspections: Guidelines for Reformers. World Bank.

Luhmann, N. (2013). Oblast. Ljubljana: Krtina.

Monk, J. (2012). Reform of Regulatory Enforcement and Inspections in OECD Countries. OECD Publishing.

Montesquieu, C. de. (1989). Montesquieu: The Spirit of the Laws. (A. M. Cohler, B. C. Miller, \& H. S. Stone, Eds.). Cambridge; New York: Cambridge University Press.

Newton. (1947). Sir Isaac Newton's Mathematical Principles of Natural Philosophy and His System of the World. (A. Motte \& F. Cajori, Eds.). Oakland: University of California Press.

OECD. (2006). Determinants of Quality in Regulatory Impact Analysis SG/ GRP(2006)3. OECD, Paris.

OECD. (2009). Regulatory Impact Analysis: A Tool for Policy Coherence. OECD.

OECD. (2013). Public Consultation on Best Practice Principles for Improving Regulatory Enforcement and Inspections. OECD Publishing. Retrieved from http://www.oecd-ilibrary.org/governance/risk-and-regulatorypolicy_9789264082939-en

OECD. (2014). Regulatory Enforcement and Inspections, OECD Best Practice Principles for Regulatory Policy. OECD Publishing.

Olson, M. (2002). The Logic of Collective Action. Cambridge: Harvard University Press.

Palast, G., Oppenheim, J., \& MacGregor, T. (2003). Democracy and regulation: how the public can govern essential services. London: Pluto Press.

Regulatory Delivery. (2017). What we do. Retrieved from https://www.gov.uk/ government/organisations/regulatory-delivery

Regulatory Scrutiny Board. (2016). Annual Report 2016 - Regulatory Scrutiny Board. European Commission, Brussels.

Schiller, R. (2016). The historical origins of American regulatory exceptionalism. In F. Bignami (Ed.), Comparative Law and Regulation: Understanding the Global Regulatory Process (pp. 55-72). Cheltenham: Edward Elgar Publishing.

SCM network. (2016). International Standard Cost Model Manual. OECD Publishing.

Stiglitz, J. A. (2009). Regulation and Failure. In D. A. Moss \& J. Cisternino (Eds.), New Perspectives on Regulation. The Tobin Project.

The High Level Group on Administrative Burdens. (2014). Cutting Red Tape in Europe. Final Report. The High Level Group on Administrative Burdens. Retrieved from http://ec.europa.eu/smart-regulation/refit/admin_burden/ docs/08-10web_ce-brocuttingredtape_en.pdf 
POVZETEK

\subsection{Izvirni znanstveni članek}

\section{Učinki predpisov zaradi dejavnosti inšpekcij}

Regulirane dejavnosti je v spreminjajočih se okoljih težko upravljati. Njihova kompleksnostje navadno višja, kotse jo običajno razume v okvirujavnih uprav, ki v večini primerov pripravljajo osnutke zakonov, odločajo v upravnih postopkih in izvajajo nadzor nad ljudmi in njihovimi dejavnostmi. Vse to, enako ali celo v večji meri velja za inšpekcije kot javne organe, ki neposredno vidijo "predpise v akciji" in ki so neposredne priče pojavu asimetrij med predpisi in njihovim izvajanjem. Inšpekcija je v kontekstu izvršilnih nalog kljub svoji starosti relativno nov in slabo razumljen element regulativnih politik. Članek temelji na ideji, da sta regulacija in njeno izvrševanje dve strani istega kovanca: le "regulacijaizvrševanje (vložki)" in "izvrševanje-regulacija" (povratne informacije) so "oči in ušesa" učinkovite regulacije. Brez slednje, ko so pravila realna in ustrezna za določen kontekst, nobena mera izvrševanja ne bo mogla sicer spremeniti nerealnih pravil v uspešna pravila. Istočasno pa brez usmerjenega izvrševanja v pravilnem zaporedju, ki je osredotočeno na analizo tveganj, obvladovanje tveganj (strateško načrtovanje na podlagi tveganj), spremljanja in zadostnih sredstev, nobena količina sicer dobro zasnovane regulacije ne bo prineslo pričakovanih rezultatov. Samo natančno razumevanje pojmov kontrole, nadzora in inšpekcije, lahko vodi k boljšemu razumevanju dela inšpekcijskega dela, ki ne sme temeljiti zgolj na represivnemu "ukazu in kontroli" (kjer moč teče enosmerno v obliki ukazov in navodil), ampak tudi na način prilagajanja, ki ga zagotavlja dvosmerna komunikacija. Funkcija nadzora torej ni nikoli le funkcija nadzora, temveč se prek njega (z "ustreznim odmerkom") tudi upravlja relevantno področje. Prihodnje raziskave na področju inšpekcij bi se lahko osredotočile na sistemsko pripravo poročil o inšpekcijskih pregledih z ločenimi odseki za poročanje o komuniciranju z zainteresiranimi deležniki in javnostjo, o nadzornih, preventivnih in represivnih ukrepih, za oceno/ upravljanje s tveganji in ne nazadnje, ali predvsem za sodelovanje ljudstva pri upravljanju javnih zadev in na druge demokratične elemente. Ne gre pozabiti, da je najboljša represivna institucija tista, ki ob doseganju ciljev nikoli ali zelo redko uporablja legalno represijo moč za namen prisile lastnih sodržavljanov.

Ključne besede: nadzor, javna uprava, inšpekcije, izvajanje, regulacija. 